Pediat. Res. 13: 1383 (1979)

\title{
Letter to the Editor: Vitamin D Toxicity and Infantile Hypercalcemic Syndrome
}

\author{
GARY M. CHAN, JOHN J. BUCHINO, AND REGINALD TSANG
}

Medical Center, Department of Pediatrics, The University of Utah, Salt Lake City, Utah, USA

We appreciate Dr. Forbes' remarks and agree with him that the evidence of vitamin D toxicity or sensitivity during pregnancy leading to infantile hypercalcemic syndrome is not conclusive.
Presently, we are conducting additional research to test the effect of maternal vitamin $\mathrm{D}$ ingestion on the fetus.




Pediat. Res. 13: 1384-1386 (1979)

ANOMALOUS $a_{2}$-MACROGLOBULIN-PROTEASE COMPLEXES

IN CYSTIC PIBROSIS : DECREASED UPTAKE OF THE COMPLEXES BY FIBROBLASTS IN CULTURE

F. VAN LEUVEN, Ph.D.

J.J. CASSIMAN, M.D.

H. VAN DEN BERGHE, M.D.

Division of Human Genetics, Department of Human Biology, University of Leuven Belgium.

\section{SUMMARY}

Immunochemical and functional properties of control and Cystic Fibrosis (CF) $a_{2}$ Macroglobulin $\left(a_{2} \mathrm{M}\right)$ are compared. Crossed immunoelectrophoresis and

two $a_{2} M$ preparations.
Trypsin-esterase activity assayed with BAPNA as a substrate, in the presence of Trypsin-esterase activity assayed with BAPNA as a substrate, in the presence an excess STI, gave similar ratios between total and active $a_{2} \mathrm{M}$. These ${ }_{2} \mathrm{M}^{\mathrm{M}}$ trypsin complexes were equally stable under various experimental and maintained a constant STI non-inhibited esterase activity. to a similar extent during a four hour period.

The only significant difference was observed when the uptake of $a_{2} \mathrm{M}$ from The only significant difference was observed when the uptake of $a_{2} M$ from untreated sera was exaine than from pooled control and CF serum did not affect the normal uptake and other serum components were take up to the normal extent. Intracellular degradation of $\mathrm{CF} a_{2} \mathrm{M}$ had a half life More to 2.8 hours, which compares well to the normal half life of 2.2 hours. More work needs to be done on the nature of the interaction between $a_{2}$ and proteases before a reasonable exp
abnormal behavior can be sought.

\section{SPECULATION}

An in vitro system is described which might be of value for the study of the molecular anomaly in the $a_{2} \mathrm{M}$-protease complex of patients with $\mathrm{CF}$. Moreover, our observations, if confirmed and extended, could represent a rapid, quantitative and reproducible assay for the detection of patients with CF. quantitative and reproducible assay for the detection of patients with possibly diagnose cystic fibrosis in amniotic fluid.

\section{INTRODUCTION}

We have recently demonstrated that $a_{2}$-Macroglobulin $\left(a_{2} M\right)$ is taken-up selectively from the growth medium by fibroblasts in culture. The uptake of $a_{2} \mathrm{M}$ is preceeded by the binding of the molecules to high af inity receptors at the cell surface, and results in rapid degradation (half life $2.2 \mathrm{hrs}$ ) of the molecules intracellularly. Moreover, comparison between the kinetic parameters of binding and uptake of purified 'native' $a_{2} \mathrm{M}$ and $a_{2} M-p r o t e a s e$ complexes indicated that this cellular property was selective for the $a_{2}$ M-protease complexes. Whereas the physiologic implications of this
process remain obscure, we could demonstrate that certain human tumor-derived process remain obscure, we could demonstrate that certain
cell lines lacked the specific surface receptor $(7,8,9)$.

cell lines lacked the specific surface receptor $(7,8,9)$.
Anomalies in the behavior of $a_{2} \mathrm{M}$, purified from the plasma of patients with Anomalies in the behavior of $a_{2} \mathrm{M}$, purified from the plasma of patients
cystic fibrosis have been described $(3,4,5,10)$. The reported anomalies cystic fibrosis have been described to of $a_{2} \mathrm{M}$-protease complexes as well as to the decreased affinity of proteases for this $\pm 750,000 \mathrm{MW}$ serum glycoprotein. The present report has examined immunochemical and functional properties of control and cystic fibrosis (CF) $a_{2} \mathrm{M}$. No differences in the immunoelectrophoretic properties of $a_{2} \mathrm{H}$ was identified. After complexation to trunsin hoth $c$, retic properties of $a_{2}$ : was identifemained stable.

Furthermore, the uptake by cultured fibroblasts of $a_{2} M-t r y p s i n$ complexes from control or $C F$ sera was similar. The only significant difference with control $a_{2} M$ was found in the variable but reduced uptake of naturally occurring $a_{2} \mathrm{M}-$ $a_{2} M$ was found in the variable but reduced uptake of naturally occurring a
protease complexes by the cells. Possible explanations for this observation
will be discussed.

\section{MATERIALS}

Blood samples were obtained from $\mathrm{CF}$ patients and their parents through the cooperation of the Belgian Cystic Fibrosis Foundation, and the Department of Pediatrics, Catholic University of Leuven. Only ambulant patients between 2 and 10 year of age with documented disease and increased sweat-chloride tests were included. Pooled control serum was obtained from the Red Cross Blood Centre, Leuven, Belgium.

The antibodies used in imnunoelectrophoresis were purchased from Dakopatts, Denmark (11). Crystalline trypsin was from Sigma (12) and Soybean trypsin inhibitor was from Calbiochem (13). Enzyme substrates were obtained from Serva (14).

METHODS

Crossed and rocket immunoelectrophoresis were carried out as described $(7,9)$. Enzymatic activity of trypsin in the presence of $a_{2} \mathrm{M}$ was determined a described by Ganrot (1). Purification of $a_{2} \mathrm{M}$ (more than $95 \%$ ) was as described (8).

Cell culture healthy volunteers. The growth medium consisted of Dulbecco's Modified Eagle's medium (DME), containing 10\% (v/v) heat-inactivated Newborn Calf Serum (NCS), $1 \mathrm{~g} / 1 \mathrm{NaHCO}_{3}, 15 \mathrm{mM} \mathrm{N}$-Tris (hydroxymethyl)-methyl-2-aminoethane sulfonic acid
(TES) and $15 \mathrm{mM} \mathrm{N}-2$-hydroxyethyl piperazine $\mathrm{N}-2$ ethane sulfonic acid (HEPES) (TES) and $15 \mathrm{mM} \mathrm{N}-2$-hydroxyethyl piperazine $\mathrm{N}-2$ ethane sulf
buffered to $\mathrm{pH} 7.5$ with iN NaOH; no antibiotics were added.

buffered to $\mathrm{pH} 7.5$ with $\mathrm{IN} \mathrm{NaOH}$; no antibiotics were added.
Cell suspensions were obtained by trypsin as follows: after decanting the Cell suspensions were obtained by trypsin as follows: af ter decanting the

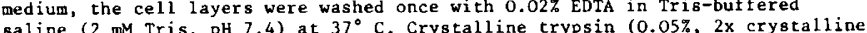
sigma, in EDTA solution), was added to the cell layer and incubation was continued for 10 min at $37^{\circ} \mathrm{C}$. Cold phosphate buffered saline (PBS) was added and the cell suspensions were centrifuged for $7 \mathrm{~min}$ at $160 \mathrm{~g}, 4^{\circ} \mathrm{C}$.

The cell pellets were resuspended in cold PBS, centrifuged, decanted and processed. If necessary
in inmunoelectrophoresis.

Uptake of $a_{2 M}$

Cl1 layers were kept in $10 \%$ rabbit serum in DME for at least $48 \mathrm{hrs}$ before the experiments. This is sufficient time to degrade all intracellular $a_{2} \mathrm{M}$ taken up from the newborn calf serum (7). Af ter three washes with serumconcentration of serum. After $4 \mathrm{hrs}$ the medium was removed, the cells washed and trypsinized and assayed for intracellular $a_{2} \mathrm{M}$ as described (7).

\section{RESULTS}

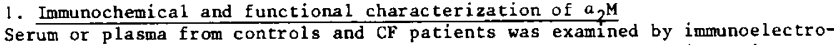
phoresis (IE) using comercial rabbit-anti-human $a_{2}$ Macroglobulin antisera. Quantitative results were obtained by rocket IE (RIE), while qualitative characteristics were examined by crossed IE (CIE). Representative pattern obtained with the latter technique for control- and $\mathrm{CF}-a_{2} \mathrm{M}$ are shown in Fig. 1. No immunochemical differences between control or $\mathrm{CF}-a_{2} \mathrm{M}$ could be detected by CIE or by Ouchterlony double diffusion. As expected (10) the levels of $a_{2} \mathrm{M}$ in CF-serum were always higher than in the control sera (Table 1).

Determination of the trypsin binding capacity of $a_{2} \mathrm{M}$ as described by Ganrot (1), is based on the ability of $a_{2} \mathrm{M}$ to protect trypsin against the inhibitory activity of the high molecular weight inhibitor of Soybean (STI). Enzyme activity under these circumstances is assayed with a low molecular weight
substrate (Benzoyl-Arginyl-Para-Nitro Anilide, BAPNA). When the levels of $a_{2} \mathrm{M}$ substrate (Benzoyl-Arginyl-Para-Nitro Anilide, BAPNA). When the levels of $a_{2} \mathrm{M}$
in serum are compared to the trypsin-esterase activity after STI addition, a in serum are compared to the trypsin-esterase activity after STI adition, a measure of the amount of active $a_{2} \mathrm{M}$ in the serum is obtained(6). The ratios of
total to active $a_{2} \mathrm{M}$ for control and $\mathrm{CF} a_{2} \mathrm{M}$ were comparable (Table I). Similar total to active $a_{2} \mathrm{M}$ for control and $\mathrm{CF} a_{2} \mathrm{M}$ were comparable (Table $\mathrm{I}$. findings were obtained for partially purified $a_{2}$ from different sera. The stability of $a_{2} \mathrm{M}$-trypsin complexes was examined by the same technique: progressive dissociation of the complexes would indeed result in a gradual increase in the sri-inhibited esterase activity and decreased total esterase activity would be in control $a_{2} \mathrm{M}$ is shown in Fig. 2 . It is clear from these results that in the esterase activity can be measured. Similar results were obtained with highly purified CF $a_{2} \mathrm{M}$. The stability of the control $a_{2} \mathrm{M}$-trypsin complexes was further examined by changing experimental conditions which might af fect the activity of the trypsin. These included, prolonged incubation at $37^{\circ} \mathrm{C}$ (up to $5 \mathrm{hrs}$ ); large excess of trypsin and or STI over $a_{2} \mathrm{M}$; elimination of $\mathrm{Ca}^{2}$ and
addition of EDTA $\left(10^{-2} \mathrm{M}\right)$. None of these modifications had a marked effect on addition of EDTA $\left(10^{-2} \mathrm{M}\right)$. None of these modifications had a marked effect the non-STI-inhibited esterase activity. Experiments performed with TosylArginyl-Methyl Ester (TAME) as substrate gave essentially the same results. threitol) and denaturating (Sodium dodecyl sulphate) conditions, showed both control and $\mathrm{CF}$ a $\mathrm{M}$ to form subunits of $85.000 \mathrm{MW}$ with concomittant disappearcontrol and $C F$ a $a_{2}$ to form subunits of 85.000 MW with concomittant disappea
ance of the band of $180.000 \mathrm{MW}$ af ter complexation with trypsin (Results not shown).

\section{Uptake of $a_{2}$-trypsin complexes by normal fibroblasts in culture} fibroblasts in culture was selective for $a_{2} \mathrm{M}$-protease complexes $(7,8,9)$. To further examine whether the $a_{2} \mathrm{M}$ of control and CF serum behaved 'normally', sera were treated with trypsin to obtain complete saturation of $a_{2} \mathrm{M}$ (7). The results indicated that the $a_{2} \mathrm{M}$-trypsin complexes from $\mathrm{CF}$ serum, were taken up to a similar extent as the complexes from control sera (Fig. 3).

3. Uptake of naturally occurring a $2 M-$ protease complexes by normal fibroblasts in culture The results thusfar described, did not indicate an aberrant behavior of $\mathrm{CF} a_{2} \mathrm{M}$ when complexed to trypsin. In a final attempt to demonstrate an anomaly in the $a_{2} \mathrm{M}$ of the CF patients the uptake of naturally occurring complexes of $a_{2} \mathrm{M}$, present in untreated serum, was examined. Uptake of $a_{2} \mathrm{M}$ was found to be dosedependent for both $\mathrm{CF}$ serum and for control serum.

However, for an equal $a_{2} \mathrm{M}$ content in the culture medium, a significant reduction $(30 z)$ in the amount of $\mathrm{CF} a_{2} M$ taken up by the cells was evident.

These observations were extended to a larger group of individual serum sample (Table 2). Without exception, the uptake of a $2^{M}$ from $C F$ sera was, although variable, lower than from pooled control serum, and lower than from individua age matched control sera. Also included in Table 2 are the results obtained with sera of obligate heterozygotes (parents of

4. Interference with uptake and intracellular degradation

To exclude interference with the uptake of $a_{2} \mathrm{M}$ by serum components or factors, which might be present in the CF sera, uptake was also measured with mixtures of normal serum and $\mathrm{CF}$ sera, from which uptake was either intermediate (serum Vr.S.) or low (serum E.C.). Mixing of the
affect the uptake of normal $a_{2} M$ (Table 2).

affect the uptake of normal $a_{2}$ (Table 2 ) . Quantitation of other serum components (albumin, $a_{1}$-anti-trypsin, and
transferrin) also taken up by the cells from serum, showed that these components transferrin) also taken up by the cells from serum, showed that these componer
were taken up to the same extent from control and CF serum, indicating the were taken up to the same extent
effect to be specific for $\mathrm{CF} a, \mathrm{M}$.

Another factor which might have contributed to the lower uptake of $a_{2} \mathrm{M}$ measured under the described conditions, is intracellular degradation. If CF $a_{2} \mathrm{M}$ would be degraded faster than control $a_{2} \mathrm{M}$, which is degraded rapidly (half
life $2.2 \mathrm{hrs}$ ), this would be reflected in our experiments by an apparent lower extent of uptake. Measurements of the intracellular degradation of $\mathrm{CF}$ a $\mathrm{a}^{\mathrm{M}}$ very similar to the results obtained on normal $a_{2} \mathrm{M}$.

\section{DISCUSSION}

The results of our investigations on the stability of a $\mathrm{M}$ upon complexation with trypsin, are in conflict with previously reported observations $(3,4,5,10)$. 
circumstances, no evidence for a lack of stability in the control a $2 \mathrm{M-trypsin}$ complexes could be obtained. Our results on the 'normal' uptake of these $a_{2} \mathrm{M-}$ trypsin complexes by fibroblasts, are consistent with a normal behavior of uptake of naturally occurring a $\mathrm{M}$-protease complexes in cystic fibrosis does uptake of naturally occurring a 2 M-protease complexes in cystic fibrosis doe suggest that an anomaly exists at the level of these complexes. Preliminary results rule-out that factors, present in the serum, might interfere with the possibility and of the potential effect of naturally occurring antibodies (2) is being undertaken. Much work needs also to be done in order to elucidate the exact nature of the interaction between $a, M$ and proteases, before a reasonable explanation for the molecular nature of this abnormal behavior can be sought. Our observations, if confirmed by others, might form the basis for a rapid, quantitative and reproducible assay for the detection of patients with CF and will be of potential value for the in vitro study of anomalies of the a ${ }_{2}$ protease complex.

\section{ACKNOWLEDGEMENTS}

This work was supported by a grant from the Belgian Cancer Fund (ASLK) and by grant $n^{\circ} 3.0025 .75$ (FGWO)

The expert technical assistance of Ms. L. Stas, M. Caems and M. Willems is gratefully acknowledged.

\section{REFERENCES}

1. Ganrot, P.o. : Determination of a Macroglobulin as trypsin-protein esterase.

2. Romeo, Costar, J., and

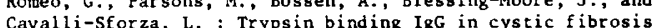
Cavalli-Sforza, L.: : Trypsin

3. Shapira, E., Ben-Yoseph, Y., and Nadler, H.L. : Abnormal breakdown of a -Macroglobulin-erypsin complex in cystic fibrosis. Clin. Chim. Acta 78 a 2 -Macrog lobulin
$359-363$ (1977).

4. Shapira, E., Martin, C.L., and Nadler, H.L. : Comparison between purified a 2 -Macroglobulin preparations from normal controls and patients with cystic a 2 -Macroglobulin preparations from normal controls
fibrosis. J. Biol. Chem. 252: 7923-7929 (1977).

5. Shapira, E., Rao, G.J.S., Wessel, H.U., and Nadler, H.L. : Absence of an a -Macroglobulin-protease complex in cystic fibrosis. Pediat. Res. 10 : $812-817$ (1976).

6. Starkey, P.M., and Barrett, A.J. : a -Macroglobulin, a physiological regulator of proteinase activity. In 'Proteinases in mamalian cells and tissues' (Ed. Barrett, A.J.) Pp. 663-696. North-Holland, Amsterdam (1977).

7. Van Leuven, F., Cassiman, J.J., and Van den Berghe, H. : Uptake and degradation of a 2 -Macroglobulin-protease complexes in human cells in culture. Exp. Cell. Res. 117: 273-282 (1978).

8. Van Leuven, F., Cassiman, J.J., and Van den Berghe, H. : Demonstration of an a -Macroglobul in receptor in human fibroblasts, absent in tumor-derived cell ${ }^{2}$ lines. J. Biol. Chem. 254: 5155-5160 (1979)

9. Van Leuven, F., Verbruggen, R., Cassiman, J.J., and Van den Berghe, H. : Demonstration of a -Macroglobulin in cultured fibroblasts, using crossed immunoelectrophoresis. Exp. Cell Res. 109: 468-471 (1977).

10. Wilson, G.B, and Fudenberg, H.H. : Studies on cystic fibrosis using isoelectric focusing. II. Demonstration of deficient proteolytic cleavage of a -Macroglobul in in cystic fibrosis plasma. Pediat. Res. 10: 87-96 (1976).

11. Dakopatts, Copenhagen, Denmark.
12. Sigma Chemical Co. Saint-Louis, Missouri, USA

13. Calbiochem, San Diego, California, USA.

14. Serva, Heidelberg, FRG.

5. Requests for reprints should be addressed to : F. Van Leuven, Division of Human Genetics, Department of Human Biology, University of Leuven, Minderbroedersstraat $12, B-3000$ Leuven, Belgium.

17. Accepted for publication August $21,1979$.

Table 1: Total and active $a_{2}$ M

\begin{tabular}{|c|c|c|c|}
\hline & $\left.\underset{(\mathrm{mg}}{a} \xi_{\mathrm{ml}}^{\mathrm{M}}\right)$ & $\begin{array}{l}\text { Trypsin activity } \\
\text { after STI } \\
\text { (units/ml) }\end{array}$ & $\begin{array}{c}\text { Ratio } \\
a_{2} \text { M/activity }\end{array}$ \\
\hline $\begin{array}{l}\text { Control serum } \\
\text { CF serum }\end{array}$ & $\begin{array}{l}1.60 \\
3.92\end{array}$ & $\begin{array}{l}0.192 \\
0.442\end{array}$ & $\begin{array}{l}0.120 \\
0.112\end{array}$ \\
\hline $\begin{array}{l}\text { Partially purified } a_{2} \text { M from : } \\
- \text { control serum } \\
\text { - CF serum }\end{array}$ & $\begin{array}{l}1.32 \\
2.05\end{array}$ & $\begin{array}{l}0.162 \\
0.218\end{array}$ & $\begin{array}{l}0.123 \\
0.106\end{array}$ \\
\hline
\end{tabular}

Control serum was obtained by pooling sera from 100 healthy blood donors: CF serum consisted of a pool of three unrelated affected children. Total $a 2^{M}$ was determined by rocket immunoelectrophoresis with anti-human $a_{2} \mathrm{M}$-antibodies as described (7). Active $a_{2} \mathrm{M}$ was determined as described by Ganrot (1). One unit of activity is defined as the amount of trypsin hydrolyzing $1 \mu$ mole of substrate (BAPNA) per minute at $25^{\circ} \mathrm{C}$. The partially purified $a_{2} M$ was obtained from the sera by gel filtration on Sephadex-G-200. ${ }_{a}{ }^{M}$ comprised about $50 z$ of the protein present in the fraction examined.
Table 2 : Uptake of ${ }_{2} \mathrm{M}$ by control fibroblasts in culture.

\begin{tabular}{ccc} 
Serum & Uptake of $a_{2} \mathrm{M}$ & Relative (z) \\
\hline Control serum (pool) & $0.32 \pm 0.03$ & 100 \\
Control serum (individual) & & \\
V.K. & 0.30 & 94 \\
K.S. & 0.26 & 81 \\
V.R.C. & 0.27 & 84 \\
B.B. & 0.33 & 103 \\
Vr.S. & 0.15 & 47 \\
E.C. & 0.02 & 6 \\
M.A. & 0.25 & 78 \\
M.L. & 0.25 & 37 \\
Vo.S. & 0.12 & 44 \\
B.W. & 0.14 & 6 \\
B.A. & 0.02 & 6 \\
S.D. & 0.02 & 19 \\
serum & 0.06 & 116 \\
Control serum + & & \\
CF serum Vr.S. & 0.37 & 109 \\
Control serum + & & \\
CF serum E.C. & 0.35 & 72 \\
Heterozygote serum & & \\
(parents Vo.S.) & & \\
Vo.C. & 0.23 & \\
W.E. & 0.24 & \\
\hline
\end{tabular}

Normal human skin fibroblasts were cultured in DME-10z rabbit serum for $48 \mathrm{hrs}$ Uptake was measured as described in the Methods Section.

The volume of serum added was adjusted to obtain a final a $M$ concentration of $200 \mu \mathrm{g}$ per ml medium. When control serum was combined with CF sera, the final $a_{2} M$ concentration was $400 \mu \mathrm{g} / \mathrm{ml}$. Uptake of $a_{2} \mathrm{M}$ is expressed as $\mu \mathrm{g}$ a $M$ per $2 \times 10^{5}$ cells after 4 hours. For control serum a pool of hundred healthy donors was used and the mean with standard deviation of 5 experiment is given. Control serum (individual) denotes sera obtained from children, age matched to the CF patients. In the last colum the results are expressed relative to the uptake with control serum.

Fig. 1 : Crossed immunoelectrophoresis of control and $\mathrm{CF}$ serum a $\mathrm{M}$. Serum $(15 \mu 1)$ was applied in the well (bottom right) and electrophoretically separated in the first dimension (anode to the left) at $10 \mathrm{~V} / \mathrm{cm}$ for 90 minutes at $5^{\circ} \mathrm{C}$. In the second dimension, the immunogel contained rabbit-anti human a M-antibodies (Dakopatts, Denmark) (11) at $3 \mu 1 / \mathrm{cm}^{2}$.

Electrophoretic conditions were $4 \mathrm{~V} / \mathrm{cm}$ for 18 hours at $15^{\circ} \mathrm{C}$.

(A) is control serum and (B) is cystic fibrosis serum (L.G.).
Concentration of $a_{2} \mathrm{M}$ in these sera were 162 and 506 mgz respectively. 


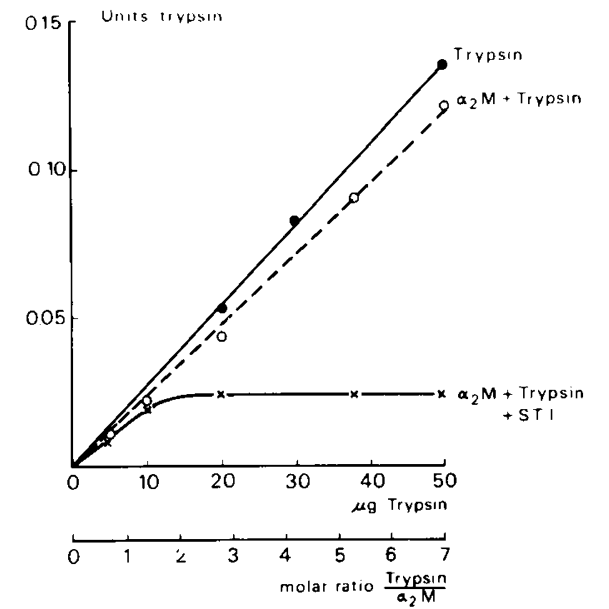

Fig. 2 : Activity of trypsin towards BAPNA in the presence of $a 2^{\mathrm{M}}$. Trypsin activity was measured spectrophotometrically as describêd (1).

- - : activity of trypsin alone

activity of trypsin in the presence of $210 \mu_{\mathrm{g} \mathrm{a}} \mathrm{M}$, assayed $30 \mathrm{~min}$

trypsin inhibitor. $210 \mu \mathrm{g} a{ }_{2} \mathrm{M}$ and $50 \mu \mathrm{g}$ Soybean and activity marem

All incubations and assays were carried out at $25^{\circ} \mathrm{C}$. The $a_{2} \mathrm{M}$ used was a All incubations and assays werained from control human plasma (8). Similar results were obtained with $a, M$ purified from CF serum.

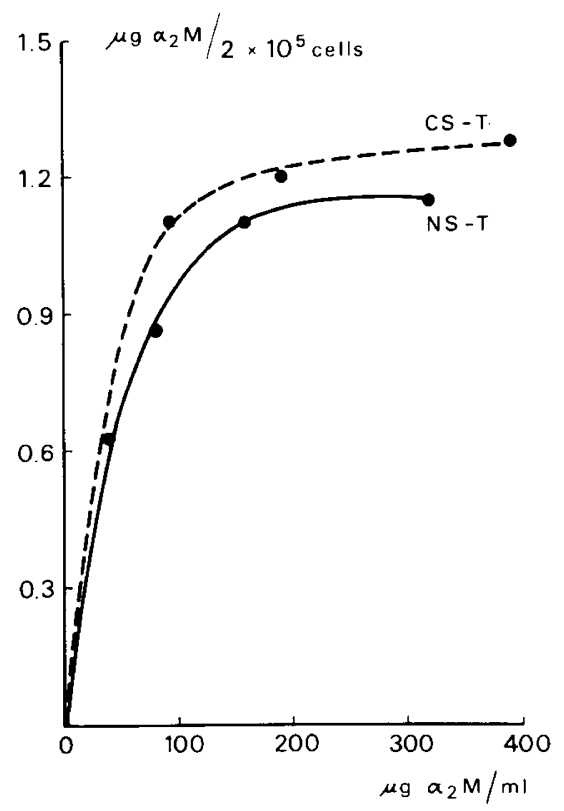

Fig. 3 : Uptake of $a{ }^{M}$ by control fibroblasts in culture.

Skin fibroblast monolayers were cultured in DME-10\% rabbit serum for 3 days. control serum (NS-T) and CF serum (CS-T) treated with trypsin as described (7), was added to the mediur

medium as indicated.
Uptake of $a_{2} \mathrm{M}$ is expressed as $\mu_{\mathrm{g}} a_{2} \mathrm{M}$ per $2 \times 10^{5}$ cells, after 4 hours

incubation at $37^{\circ} \mathrm{C}$. All points are the mean of two determinations on separate cell layers.

Copyright (C) 1979 International Pediatric Research Foundation, Inc. Printed in U.S.A.

$0031-3998 / 79 / 1312-1384 \$ 02.00 / 0$ 